\title{
IMPLEMENTATION OF PROBLEM BASED LEARNING MODEL TO IMPROVE CREATIVE THINKING ABILITY
}

\section{PENERAPAN MODEL PEMBELAJARAN PROBLEM BASED LEARNING UNTUK MENINGKATKAN KEMAMPUAN BERPIKIR KREATIF}

\author{
By: \\ Dwi Tursina Utari \\ Accounting Education Study Program Yogyakarta State University \\ dwitursina_utari@yahoo.com \\ Rr. Indah Mustikawati \\ Lecturer in Accounting Education Department Yogyakarta State University \\ i_mustikawati@uny.ac.id
}

\begin{abstract}
This research is Classroom Action Research (CAR). The research aims to improve the Creative Thinking Ability of students class XI Accounting 2 in taxation subject at SMK Negeri 1 Yogyakarta academic year 2016/2017 by implementation of Problem Based Learning Model. The research conducted in two cycle. Each cycle consisted of four stages: planning stage, implementation stage, observation stage, and reflection stage. The technique applied for collecting data was observation, test, and documentation. The results: (1) According to the observation result and the Creative Thinking Ability post-test result from the cycle I at the amount of 52,01 increased to be 76,43 after the action in the cycle II. (2) According to the amount of students' percentage who achieved the successful action, there is an increase for amount $65,32 \%$ from $9,68 \%$ in the cycle I to $75 \%$ in cycle II.
\end{abstract}

Keywords: Problem Based Learning Model, Creative Thinking Ability of Student

\begin{abstract}
Abstrak
Jenis penelitian ini adalah Penelitian Tindakan Kelas (PTK). Penelitian ini bertujuan untuk meningkatkan Kemampuan Berpikir Kreatif siswa kelas XI Akuntansi 2 pada mata pelajaran perpajakan di SMK Negeri 1 Yogyakarta tahun ajaran 2016/2017 dengan penerapan model pembelajaran Problem Based Learning. Penelitian ini berlangsung selama dua siklus. Masing-masing siklus terdiri dari empat tahap: tahap perencanaan, tahap pelaksanaan, tahap observasi, dan tahap refleksi. Teknik pengumpulan data dilakukan dengan metode observasi, tes, dan dokumentasi. Hasil dari penelitian ini adalah: (1) Berdasarkan hasil observasi dan post-test Kemampuan Berpikir Kreatif pada siklus I sebesar 52,01 meningkat menjadi 76,43 setelah dilaksanakan tindakan pada siklus II. (2) Berdasarkan dari persentase jumlah siswa yang mencapai keberhasilan tindakan terdapat peningkatan 65,32\% yaitu dari 9,68\% pada siklus I menjadi 75\% pada siklus II.
\end{abstract}

Kata kunci: Model Pembelajaran Problem Based Learning, Kemampuan Berpikir Kreatif Siswa

\section{INTRODUCTION}

The progress of a nation can be measured by the human resources, by looking at the success of the nation's education. The higher level of education that is owned by the nation can be interpreted that nations are more advanced, by continuously developing of science and technology. Because education is an effort to develop students' skills and personality through the process or activity (teaching, mentoring, or training) and interaction with the environment to be a human being (Arifin, 2013: 39). 
In the learning process, students are required to memorize a various information that not only originate on one subject, so the brain is forced to recall and hoard information. The students are not taught to develop their thinking skills. It makes the students understand in the theory only and cannot apply it in daily life. The problem is on the learning process when teacher teach the students. Most of the teachers still use traditional teaching methods and explain the subject material by using speech method. The students only listen and record what is being taught by the teacher. Thus, the learning process requires the students to memorize the learning material.

The teacher as the actor in the learning process is not only required to be able to manage the class, but they must also have good teaching skills. The teacher is expected to know a set of supporting learning process, such as media, models, strategies, methods, and others to support the learning process and can develop the skills. Its use of the learning process with an innovative and creative. Basically, the goal of learning is to produce students who have knowledge and skill in problem solving. Therefore, the learning process is not only focused on getting much knowledge, but how students use their knowledge to deal with new situations and solve problems they would encounter in the community.

In fact, teachers still used the same method in teaching. For example, using the speech method. It is similar to the researcher discovered when made an observation on March $2^{\text {nd }}, 2016$ in class X Accounting 2. Teacher were teaching used speech method, meanwhile students listen to the teacher's explanations and occasionally answered questions given by the teacher. In addition, when the researcher do PPL (Praktik Pengalaman Lapangan) from July to September 2016 in SMK Negeri 1 Yogyakarta teacher still used speech method, so the characteristics of learning was teacher centered, and students just record the material.
Based on the observation result during $P P L$ on taxation subject in class XI Accounting 1 and 2 in discussion showed that, the students have not been able to speak up a lot of ideas, cannot relate global issues because students stuck to the theory in the book, and no one dare to speak their ideas on the question asked by the audience except the presentator. So, teacher cannot show the students' Creative Thinking Ability during the discussion process and the learning process. In class XI Accounting 1 , from 31 students there are 23 students $(74,19 \%)$ and in class XI Accounting 2 from 32 students there are 27 students $(84,38 \%)$ have not been able to speak up a lot of ideas. Meanwhile, in class XI Accounting 1 there are 16 students $(51,61 \%)$ and in class XI Accounting 2 there are 22 students $(68,75 \%)$ cannot relate the problem into learning material. Besides that, in class XI Accounting 1 and 2 no one dare to speak their ideas on the question asked by the audience except the presentator. From the observation result during $P P L$, students class XI Accounting 2 have higher percentage rather than class XI Accounting 1. So, teacher could not know all students' Creative Thinking Ability during the discussion process.

According to Utami Munandar in Ali \& Asrori (2004: 41), the students have creativity if students has the ability to reflect fluency, flexibility and originality in thinking and the ability to elaborate an idea. Based on the observation result, the students' Creative Thinking Ability class XI Accounting 2 is low. In addition, the speech method which is used by teacher SMK Negeri 1 Yogyakarta in the learning process does not encourage critical attitude, active, and tend to test the students' memory only. While in school, students should not only listen to the teacher's explanation or participate in discussions, but also build personal knowledge for dealing with problems in the community. As a consequence, the students obstructed and do 
not have the ability to face a problem that requires students' creative thinking.

Efforts to grow students' Creative Thinking Ability to solve problems train certainly needed renewal methods, media, models, strategies, and others to support the learning process. Creative Thinking Ability is not only required students to be active in the learning process, but train students in developing their thinking skill. Creative Thinking Ability included creativity to face the problem, creativity to speak up ideas, and creativity to answer any questions that must be done during the discussion session. Thus, students will explore their creativity and not only be silent during the lesson.

One way that can be used to improve the Creative Thinking Ability in students is using Problem Based Learning Model. Based on the research by Suparman \& Husen (2015) the implementation of Problem Based Learning Model can improved the Creative Thinking Ability of students class VII-3 SMP Negeri 12 Kota Tidore Kepulauan. In addition, research by Putra (2012) the Creative Thinking Ability of students can improved by implementation of Problem Based Learning Model because the model gives the opportunity for students to develop their ideas so can improved the students' Creative Thinking Ability. In a study using Problem Based Learning Model, students are faced with a problem that occurs in a daily life then they are assigned to find the solutions. The solutions from the students, show how creative they are to solve problems because they are trained to develop their creative ideas.

According to Arends in Suprihatiningrum (2013: 215), Problem Based Learning Model is an approach learning, which students work on authentic problems to construct their own knowledge, develop inquiry and higher-order thinking skills, build independence and selfconfidence. In this Problem Based Learning Model, students faced a problem related to the learning material in order to make them become independent and have the ability to think creatively. It is necessary because later when they face a problem and deal in the neighborhood, they can use it as the knowledge to solve the problem. Teacher in the learning process uses Problem Based Learning Model as a facilitator and not only the material source in the classroom. Problem Based Learning Model can grow Creative Thinking Ability through a problem that faced to the students so they will be trained to think creatively in solving problems through discussion and question and answer in a group.

In fact, the taxation teacher in SMK Negeri 1 Yogyakarta have not completely develop the students Creative Thinking Ability. The teacher always uses the speech method in the learning process. So, it makes the students to memorize the theory only, not train to solve a problem using their knowledge and it show how creative they are while find the solutions of the problem.

\section{RESEARCH METHOD}

This research belongs to Classroom Action Research (CAR). The research conducted in two cycles. Each cycle consisted of four stages: planning stage, implementation stage, observation stage, and reflection stage. The research was conducted in SMK Negeri 1 Yogyakarta which is located in Kemetiran Kidul street, number 53, Pringgokusuman, Gedong Tengen, Yogyakarta.

The subject of this research is all students class XI Accounting 2 at SMK Negeri 1 Yogyakarta which numbers 32 students and the object of this research is the Creative Thinking Ability of students class XI Accounting 2 in taxation subject at SMK Negeri 1 Yogyakarta academic year 2016/2017.

The data collection technique in this research use observation, test, and documentation. The observation uses to observe the students' Creative Thinking Ability in the learning process using Problem Based Learning Model in fluency thinking skills, original thinking skills, and 
detailing or elaborating thinking skills. The test are consist of pre-test and post-test of Creative Thinking Ability. The Creative Thinking Ability pre-test given to the students at the beginning of the learning process and it is to determine the students' Creative Thinking Ability before the action. The Creative Thinking Ability post-test is given to the students to determine the students' ability after the action. The documentation in this research use to take secondary data and to take a photo during the learning process using Problem Based Learning Model.

\section{FINDING AND DISCUSSION}

This research was carried out in order to improve the students' Creative Thinking Ability in taxation subject using Problem Based Learning Model at SMK Negeri 1 Yogyakarta academic year 2016/2017.

The research conducted in two cycle. Each cycle consist of four stages: planning stage, implementation stage, observation stage, and reflection stage. The cycle I and cycle II, the planning stage are prepare the lesson plan, the learning material, the learning media, the Creative Thinking Ability pre-test and post-test, case discussion in the learning process using Problem Based Learning Model, observation sheet and observation guidelines, field notes, and a student number. The implementation stage consist of introduction, core, and closing. The observation done by three observers. The observers observed the students' Creative Thinking Ability during the learning process using Problem Based Learning Model with the observation sheet and observation guidelines. Reflection stage done by examining the observation result during the learning process. There are the observation result of Creative Thinking Ability of students during the learning process using Problem Based Learning Model and the Creative Thinking Ability pre-test and posttest. From the observation result and the Creative Thinking Ability post-test can be show the successful action in each cycle when $75 \%$ of the total students can achieve a score of observation result and a score of the Creative Thinking Ability post-test at least 75 .

The results of the implementation of Problem Based Learning Model to improve the Creative Thinking Ability of students class XI Accounting 2 in taxation subject at SMK Negeri 1 Yogyakarta academic year 2016/2017 on the cycle I and cycle II are:

1. The Creative Thinking Ability Pre-test and Post-test

The Creative Thinking Ability pretest and post-test that is used in this research consist of four essay: two language test (verbal) and two images test (figural test). The pre-test and posttest question arrange based on the lattice of Creative Thinking Ability test and refers to Wijaya Sunarya (2014: 72) and based on the indicator developed from the characteristics of Creative Thinking Ability, there are fluency thinking skills, original thinking skill, and detailing or elaborating skills. The average of pre-test and post-test result on cycle I and cycle II shows an improvement. There are:

Table 1. The Improvement of Creative Thinking Ability Pre-test and Post-test Result From Cycle I to Cycle II

\begin{tabular}{|c|c|c|c|c|}
\hline \multirow[b]{2}{*}{$\begin{array}{l}\text { Descrip- } \\
\text { tion }\end{array}$} & \multicolumn{2}{|c|}{ Cyle I } & \multicolumn{2}{|c|}{ Cycle II } \\
\hline & $\begin{array}{l}\text { Pre- } \\
\text { test }\end{array}$ & $\begin{array}{c}\text { Post- } \\
\text { test }\end{array}$ & $\begin{array}{l}\text { Pre- } \\
\text { test }\end{array}$ & $\begin{array}{c}\text { Post- } \\
\text { test }\end{array}$ \\
\hline Average & 52,96 & 56,45 & 68,75 & 93,49 \\
\hline
\end{tabular}

2. The Observation of Creative Thinking Ability

The Creative Thinking Ability observation of students class XI Accounting 2 at SMK Negeri 1 Yogyakarta academic year 2016/2017 on taxation subject was implemented during the learning process using 
Problem Based Learning Model. The observation is done by three observers by observation sheet and observation guidelines. Observer observes the students Creative Thinking Ability individually.

In the process of observation, the observer observes the characteristics of Creative Thinking Ability there are fluency thinking skills, original thinking skills, and detailing or elaborating skills. The characteristics of Creative Thinking Ability are described by an indicator that observe during the learning process. The indicators of Creative Thinking Ability:

1) Fluency thinking skills

a) Student asks a question when learning process (Indicator A).

b) Student is able to answer questions from the teacher or other students (indicator B).

2) Original thinking skills: student is able to give answers to questions that come from his own mind (indicator $\mathrm{C}$ ).

3) Detailing or elaborating skills: student is able to express the reason of answers the questions that successfully addressed the student (indicator D).

Based on the observation result has been done on the cycle I and cycle II, the total score each Creative Thinking Ability indicator of students can be seen in the following table:

Table 2. Score Obtained by Students Each Indicator on Cycle I

\begin{tabular}{|c|c|c|}
\hline \multirow{2}{*}{ Score } & \multicolumn{2}{|c|}{$\begin{array}{c}\text { Indicator of Creative } \\
\text { Thinking Ability }\end{array}$} \\
\cline { 2 - 3 } & \multicolumn{2}{|c|}{$\mathbf{A}$} \\
\cline { 2 - 3 } & $\begin{array}{c}\text { Amount of } \\
\text { Student }\end{array}$ & $\%$ \\
\hline 1 & 28 & 90,32 \\
\hline 2 & 2 & 6,45 \\
\hline 3 & 1 & 3,23 \\
\hline & 31 & 100 \\
\cline { 2 - 3 } & \multicolumn{2}{|c|}{ B } \\
\hline
\end{tabular}

\begin{tabular}{|c|c|c|}
\hline \multirow{2}{*}{ Score } & \multicolumn{2}{|c|}{$\begin{array}{c}\text { Indicator of Creative } \\
\text { Thinking Ability }\end{array}$} \\
\cline { 2 - 3 } & \multicolumn{2}{|c|}{ A } \\
\cline { 2 - 3 } & $\begin{array}{c}\text { Amount of } \\
\text { Student }\end{array}$ & $\%$ \\
\hline 1 & 17 & 54,84 \\
\hline 2 & 9 & 29,03 \\
\hline 3 & 5 & 16,13 \\
\hline \multirow{2}{*}{} & 31 & 100 \\
\cline { 2 - 3 } & \multicolumn{2}{|c|}{$\mathrm{C}$} \\
\hline 1 & 19 & 61,29 \\
\hline 2 & 5 & 16,13 \\
\hline 3 & 7 & 22,58 \\
\hline & 31 & 100 \\
\hline & \multicolumn{2}{|c|}{$\mathrm{D}$} \\
\hline 1 & 25 & 80,64 \\
\hline 2 & 1 & 3,23 \\
\hline 3 & 5 & 16,13 \\
\hline & 31 & 100 \\
\hline
\end{tabular}

Based on the Creative Thinking Ability observation result on cycle I, the indicator A there were 28 students $(90,32 \%)$ get score 1,2 students $(6,45 \%)$ get score 2 , and 1 student $(3,23 \%)$ get score 3 . On the indicator B, there are 17 students $(54,84 \%)$ get score 1,9 students $(29,03 \%)$ get score 2 , and 5 students $(16,13 \%)$ get score 3 . On the indicator $\mathrm{C}$, there are 19 students $(61,29 \%)$ get score 1,5 students $(16,13 \%)$ get score 2 , and 7 students get score 3 . On the indicator $\mathrm{D}$, there are 25 students $(80,64 \%)$ get score 1,1 students $(3,23 \%)$ get score 2 , and 5 students $(16,13 \%)$ students get score 3 . It means that based on the observation result on each indicator most of the students obtained score 1. While the score 2 and 3 obtained only some students. Because during the learning process teacher has not been optimally digging the students Creative Thinking Ability. In addition, students' participation in the learning process is low. So, the students Creative Thinking Ability on taxation subject in the cycle I have not been optimal. 
Table 3. Score Obtained by Students of Each Indicator on Cycle II

\begin{tabular}{|c|c|c|}
\hline \multirow{2}{*}{ Score } & \multicolumn{2}{|c|}{$\begin{array}{c}\text { Indicator of Creative } \\
\text { Thinking Ability }\end{array}$} \\
\cline { 2 - 3 } & \multicolumn{2}{|c|}{ A } \\
\cline { 2 - 3 } & $\begin{array}{c}\text { Amount of } \\
\text { Student }\end{array}$ & \% \\
\hline 1 & 15 & 46,88 \\
\hline 2 & 6 & 18,75 \\
\hline 3 & 11 & 34,37 \\
\hline \multirow{3}{*}{} & 32 & 100 \\
\hline 1 & 16 & B \\
\hline 2 & 7 & 21,87 \\
\hline 3 & 9 & 28,13 \\
\hline \multirow{2}{*}{} & 32 & 100 \\
\hline 1 & 12 & C \\
\hline 2 & 16 & 37,5 \\
\hline 3 & 4 & 50 \\
\hline \multirow{2}{*}{} & 32 & 12,5 \\
\hline 1 & 17 & 53,13 \\
\hline 2 & 7 & 21,87 \\
\hline 3 & 8 & 25 \\
\hline & 32 & 100 \\
\hline & \multicolumn{2}{|c|}{} \\
\hline
\end{tabular}

Based on the Creative Thinking Ability observation result on cycle II, on indicator A there are 15 students $(46,88 \%)$ get score 1,6 students $(18,75 \%)$ get score 2 , and 11 students $(34,37 \%)$ get score 3 . On indicator B there are 16 students $(50 \%)$ get score 1 , 7 students $(21,87 \%)$ get score 2 , and 9 students $(28,13 \%)$ get score 3 . On indicator $\mathrm{C}$ there are 12 students $(37,5 \%)$ get score 1,16 students $(50 \%)$ get score 2 , and 4 students $(12,5 \%)$ get score 3 . On the indicator $\mathrm{D}$ there are 17 students $(53,13 \%)$ get score 1,7 students $(53,23 \%)$ get score 2 , and 8 students $(25 \%)$ get score 3 . So, the observation result indicate an improve in the acquisition of score obtained by students on cycle II. It looks on the number of students who obtained observation score each indicator of 2 and 3 are improved, meanwhile score 1 are decrease.

3. The Successful Action of the Students Creative Thinking Ability From Cycle I to Cycle II

The successful action in this research is when $75 \%$ of total students can achieve a score of observation result and Creative Thinking Ability post-test at least 75. The students can be said achieved the successful action when an amount of observation result and the Creative Thinking Ability post-test at least get a mark of 75. It is obtained from the Creative Thinking Ability observation result of students during the taxation learning using Problem Based Learning Model and after answering the Creative Thinking Ability post-test.

So the successful action each cycle can be known after calculating the score of observation result and the score of the Creative Thinking Ability post-test all students. Then calculate the average of the class. The result will show has reached the criteria of successful action or not, show from how many students who get the minimum mark of 75 .

There is table to describe the improvement of Creative Thinking Ability successful action of students class XI Accounting 2 at SMK Negeri 1 Yogyakarta academic year 2016/2017 from the cycle I to cycle II: 
Table 4. The Creative Thinking Ability Successful Action of Students Class XI Accounting 2 from Cycle I to Cycle II

\begin{tabular}{|c|l|c|c|}
\hline No. & $\begin{array}{c}\text { Descrip- } \\
\text { tion }\end{array}$ & $\begin{array}{c}\text { The } \\
\text { Success- } \\
\text { ful } \\
\text { Action } \\
\text { Cycle I }\end{array}$ & $\begin{array}{c}\text { The } \\
\text { Successful } \\
\text { Action } \\
\text { Cycle II }\end{array}$ \\
\hline 1 & $\begin{array}{l}\text { The average } \\
\text { of score } \\
\text { observation } \\
\text { and post-test }\end{array}$ & 52,01 & 76,43 \\
\hline 2 & $\begin{array}{l}\text { Highest } \\
\text { mark }\end{array}$ & 87,5 & 91.67 \\
\hline 3 & $\begin{array}{l}\text { Lowest } \\
\text { mark }\end{array}$ & 33,33 & 50 \\
\hline 4 & $\begin{array}{l}\text { Students } \\
\text { who achieve } \\
\text { the } \\
\text { successful } \\
\text { action }\end{array}$ & 3 & 24 \\
\hline 5 & $\begin{array}{l}\text { The } \\
\text { percentage } \\
\text { of students } \\
\text { who achieve } \\
\text { the } \\
\text { successful } \\
\text { action }\end{array}$ & $9,68 \%$ & $75 \%$ \\
\hline
\end{tabular}

Source: primary data

Based on the Table 4, showed the average of score observation and posttest on the cycle I for amount 52,01 become 76,43 after the implementation of cycle II. There are indicates an improvement the Creative Thinking Ability from the cycle I to cycle II for amount 24,42 . In terms of the amount of students who achieve the successful action, on the cycle I from 31 students who attend in the class there are 3 students $(9,68 \%)$ who had been obtained a mark at least 75 . After the implementation on the cycle II from 32 students who attend in the class there are 24 students $(75 \%)$ had been obtained a mark at least 75 .
Based on the explanation, the improvement of the average of score observation and post-test from the cycle I to cycle II can be seen in the graphic chart below:

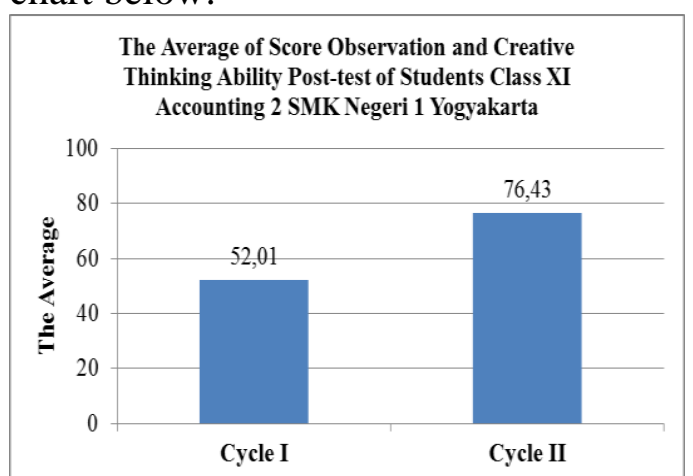

Figure 1. The Graphic Chart of Improvement the Average of Score Observation and Post-test from Cycle I to Cycle II

Based on the Figure 1, the average of score observation and post-test on the cycle I for amount 52,01 becomes 76,43 after the implementation of cycle II. There are 24,42 improved from the cycle I to cycle II.

In terms of improving the students who achieve the criteria of successful action can be seen in the graphic chart below:

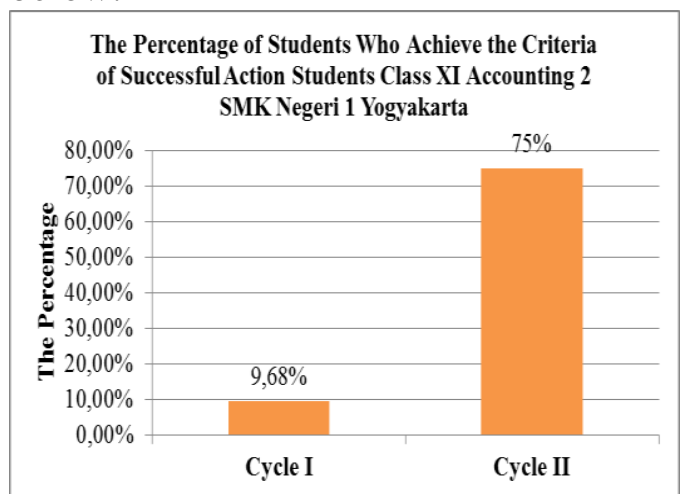

Figure 2. The Graphic Chart of Improvement the Percentage of Students Who Achieve the Criteria of Successful Action from Cycle I to Cycle II 
Based on the Figure 2, there are an improve the percentage of students who achieved the criteria of successful action from the cycle I to cycle II. Based on the cycle I, the students who achieved the criteria of successful action for amount 3 students or $9,68 \%$ reached a mark of observation result and post-test at least 75 . Based on the cycle II, the student who achieves the criteria of successful action for amount 24 students or $75 \%$ reached a mark of observation result and post-test at least 75. There is an improvement for amount $65,32 \%$.

Accordance with the criteria of successful action in research method, the implementation of Problem Based Learning Model can improve the Creative Thinking Ability of students class XI Accounting 2 on taxation subject when $75 \%$ of total students can achieve a score of observation result and Creative Thinking Ability post-test at least 75. Anghileri in Beetlestone (2012: 29-30) explained that a creative approach has a real benefit for the development of student mathematical ability. From the class action research, it is shown that through the creative approach is the Creative Thinking Ability has benefit for the development of the students' taxation ability class XI Accounting 2 to think creatively during the learning process by implementation of Problem Based Learning Model. Can be concluded that the implementation of Problem Based Learning Model on taxation subject has been able to improve the students' Creative Thinking Ability in class XI Accounting 2 at SMK Negeri 1 Yogyakarta academic year 2016/2017 based on the research result.

\section{CONCLUSIONS AND SUGGESTIONS Conclusions}

The implementation of Problem Based Learning Model can improve the Creative
Thinking Ability of students class XI Accounting 2 in taxation subject at SMK Negeri 1 Yogyakarta academic year 2016/2017, it shown by: (1) The improvement of the average score of observation result and Creative Thinking Ability post-test from the cycle I to cycle II. On the cycle I the average is 52,01 and the cycle II the average is 76,43 . There is improved for amount 24,42. (2) In term of the students' percentage who achieve the criteria of successful action, on cycle II $75 \%$ (24 students) had been achieved the criteria of successful action predetermined. The criteria of successful action in this research is $75 \%$ of students can achieve the mark of successful action at least 75 .

\section{Suggestions}

Based on the results of the implementation of Problem Based Learning Model to improve the students' Creative Thinking Ability in taxation subject at SMK Negeri 1 Yogyakarta academic year 2016/2017, the suggestions go as follows:

a. The teacher should implement Problem Based Learning Model in other subjects, because the learning model can improve the students' Creative Thinking Ability in the taxation subject. So, students can learn independently, train the Creative Thinking Ability, and the characteristic of the learning process is student centered.

b. For the next researcher is expected to make a better decision for the research time. So the research can be implemented fluently and optimally.

\section{REFERENCES}

Ali, Mohammad \& Asrori, Mohammad. (2006). Psikologi Remaja Perkembangan Peserta Didik. Jakarta: Bumi Aksara.

Arifin, Zainal. (2013). Evaluasi Pembelajaran. Bandung: Remaja Rosdakarya.

Beetlestone, Florence. (2012). Creative Learning. Bandung: Nusa Media. 
Putra, Tomi Tridaya, et al. (2012). "Meningkatkan Kemampuan Berpikir Kreatif Siswa dengan Pembelajaran Berbasis Masalah". Jurnal Pendidikan Matematika Vol.1 (Part 3: Hal. 22-26). Accessed on January 30 ${ }^{\text {th }}, 2017$ from: http://journal.unnes.ac.id/artikel_sju/jpe 12985.

Suparman \& Husen, Dwi Nastuti. (2015). "Peningkatan Kemampuan Berpikir Kreatif Siswa Melalui Penerapan Model Problem Based Learning Model". Jurnal Bioedukasi Vol.3 No.2 (Hal. 367-372). Accessed on January $30^{\text {th }}$,

2017from:http://ejournal.unkhair.ac.id/i ndex.php/bioedu/article/download/109/ 83.

Suprihatiningrum, Jamil. (2013). Strategi Pembelajaran: Teori \& Aplikasi. Yogyakarta: Ar-Ruzz Media.

Wijaya Sunarya, Eny. (2014). "Efektivitas Model Pembelajaran Treffinger dalam Meningkatkan Kemampuan Berpikir Kreatif dan Prestasi Belajar Peserta Didik Kelas X Pada Mata Pelajaran Kewirausahaan di SMK Muhammadiyah 2 Yogyakarta Tahun Ajaran 2013-2014". Undergraduate Thesis. Yogyakarta State University. 